\title{
Implementation of Medicine Take-back Concept at Community Level in Nepal: A Feasibility Study
} \author{
9866 \\ Anil Giri \\ Pokhara University \\ Bigyan Bhatta \\ Nobel College \\ Krishna Awasthi \\ Nobel College \\ Kiran Bhurtyal \\ Nobel College \\ Bimala Joshi \\ Nobel College \\ Khem Raj Joshi \\ Pokhara University
}

Binaya Sapkota ( $\nabla$ sapkota.binaya@gmail.com )

Nobel College Faculty of Health Sciences, Department of Pharmacy, Sinamangal, Kathmandu, Pokhara University, Nepal https://orcid.org/0000-0002-4125-

Research

Keywords: Community, take-back program, unwanted, unused and expired medicines, Nepal

Posted Date: September 8th, 2020

DOI: https://doi.org/10.21203/rs.3.rs-68526/v1

License: (c) (1) This work is licensed under a Creative Commons Attribution 4.0 International License. Read Full License 


\section{Abstract}

Background: Medications are not always completely consumed as purchased from pharmacy due to lack of awareness, forgetfulness. So, most households may have leftover, unwanted, unused and expired (UUE) medicines. They may lead to health hazards and environment pollution. The present study was aimed to analyze feasibility of implementation of medicine take-back in select communities of Nepal.

Methods: Exploratory study was conducted among adults (total 400) in Kathmandu, Lalitpur, Kaski, Kanchanpur and Kailali districts from July 2017 to January 2018. Study sites and participants were selected by simple random sampling and respondents were interviewed about their awareness about medicine disposal techniques, possible hazards and their willingness to support take-back program using semi-structured questionnaire. Multinomial logistic regression analysis was applied to explore the relationship of various take-back related outcomes with the predictors. The $\mathrm{p}$-value less than 0.05 was statistically significant at $95 \%$ confidence level.

Results: The multinomial logistic regression analysis showed that there was significant relationship of health hazards (rashes and diarrhea) among the farmers, engineers, nurse and lawyers ( $p$ value $<0.01$ in each). Land pollution and effect on health of children was significantly related with the inappropriate disposal of medicines such as site of disposal ( $p$ value $<0.01$ ), river ( $p$ value 0.02 ), garbage ( $p$ value 0.04 ), and dumping site ( $p$ value 0.01 ). The analysis of the willingness to follow take-back program with the techniques of support showed significant relationship with the establishment of collection center and participation on seminar ( $p$ value $<0.01$ ).

Conclusions: Most participants kept UUE medicines in home, disposed with household rubbish and flushed down the sink. They were interested to support take-back, if implemented in their community but the main constraint was the budget. Hence, take-back concept could be initiated and implemented on government funding or other external sources.

\section{Key Messages Regarding Feasibility}

- No published evidence regarding medicine take-back is available in Nepal, indicating the rationale of the present study.

- Analysis of the willingness to follow take-back program with the techniques of support showed significant relationship with the establishment of collection center and participation on seminar ( $p$ value $<0.01$ ).

- Take-back concept could be initiated and implemented on government funding or other external sources.

\section{Background}

Medications (prescription-only i.e., POM or over-the-counter i.e., OTC) may not always be completely consumed as purchased from the hospital or community pharmacy. As a result, most households have leftover, unwanted, unused and expired (UUE) medicines which may harm the humans, and the environment, if discarded or disposed improperly [1]. They may also be accumulated due to the death of a family member consuming the medicines, amelioration of existing health condition, medication discontinuation and non-adherence to medications and other [2-4]. About 50\% patients discontinue their medications within a few months of initiation of therapy as they forget to maintain the dosing schedule (especially in case of dementia, Alzheimer's disease), experience untoward effects (such as any idiosyncratic or predictable reactions), perceive no amelioration in health condition with medicine consumption (especially in case of chronic diseases), or feel problem resolved amidst the medication schedule (especially in case of tuberculosis, leprosy or other antimicrobials use) [2]. Extent of the UUE medicines was $42 \%$ in the USA, $44.7 \%$ in Spain, $38.8 \%$ in Iran, and $25.8 \%$ in Saudi Arabia, all indicating it as one of the cross-border problems [5].

Unsafe disposal practice is rampant throughout world. Medicines over-prescribed may also increase the disposal of UUE medicines [6]. Unused medicines collection program in California (USA) showed that 50\% OTC and 45\% POM were discarded unused [7-11]. Disposal practice at healthcare facilities (HCFs) is regulated by the concerned states but remains undetected and unregulated at household levels even in the USA [12-14]. The health care facilities (HCFs) can follow reverse distribution mechanism where they sort the UUE drugs, send for disposal and may return to the manufacturers [15].

In the USA, Marin County commenced medicine take-back program in 2005 to reduce the burden of household pharmaceutical waste [10]. Similarly, New Zealand, and Canada also launched Disposal of Unwanted Medication Properly (DUMP) campaign and ENVIRx disposal program respectively [7, 9]. Belgium, France, Luxembourg, Portugal, Spain, Denmark, Finland, Germany, Italy, Sweden, and the UK are running take-back programs through pharmacies in collaboration with public or private waste contractor [15]. Demands for the community-based medicine take-back programs conducted by pharmacies (either single day event or perpetual) are on increasing trend in the UK and the USA, and these are responding effectively to the needs of community people [7, 13, 16]. In 2007, the Office of National Drug Control Policy (ONDCP) issued national guidelines for safe disposal of POM at household levels, focusing on the medicine take-back concept [17]. In 2004, Alachua County Environmental Protection Department (ACEPD) collected 305 pounds of unwanted residential pharmaceutical products with the investment of USD 15,944 for the pilot project at 12 locations (pharmacies, clinics) and rendered them to the hazardous waste disposal facility for incineration. Similarly, Kendall County started take-back programs on July 2007 and focused on source-segregation of controlled drugs from other non-hazardous ones [15]. Pharmaceutical waste may have serious ecological, economical and ethical consequences [18].

Community people may not have sufficient idea and awareness about the hazards of the UUE medicines but may have willingness to dispose them properly, provided that proper management system be implemented at their local levels. Abruquah et al. revealed that $98 \%$ of residents of Konongo-Odumasi in the Ashanti region of Ghana had positive intentions to dispose the UUE medicines present in their homes properly. They demanded that planning, implementation, monitoring, evaluation and reassessment of public education program and guidelines on safe disposal and the organized method of collection be introduced urgently in Ghana [19]. 


\section{Methods}

\section{Study aims and objectives}

Large-scale UUE disposal initiatives are not immediately possible in resource-constraint country like Nepal due to multitude of factors such as lack of public awareness, monetary and regulatory reasons. So, this study aimed for feasibility of the implementation of take-back concept in select Nepalese communities to make policymakers aware about its necessity and significance and focus on operational research (i.e., policy-based) in the future. Exploration of various constraints for the successful implementation of the concept was the primary perceived outcome of the present study. Sensitization of the concerned authorities to devise policies and initiate crucial steps to address the issue of haphazard medicine disposal in the local levels were the secondary outcomes.

\section{Study design and setting}

Exploratory study was carried out among the adults in local communities of 5 places- Kathmandu, Lalitpur, Kaski district (Pokhara), Kanchanpur district (Mahendranagar) and Kailali district (Dhangadhi) from July 2017 to January 2018. These study sites were selected for the study purpose by applying simple random sampling among 77 districts in Nepal. They also have wide range of population distribution with high illiteracy rates as revealed by the census 2011 in Nepal [20].

\section{Ethics approval}

Ethics approval was taken from Pokhara University Institutional Review Committee (PUIRC), Kaski, Nepal (109/074/75). Participants were ensured about all aspects of the study along with the objectives of the research. Verbal and written consents were obtained from each participant. Confidentiality of the information provided by the participants was maintained throughout the research period. For this, coding was applied and participant's identity was not disclosed beyond the research team.

\section{Characteristics of participants}

\section{Inclusion criteria}

Adults residing in the select communities of five districts were included for the study.

\section{Exclusion criteria}

Participants below age of 16 years were excluded from the study, taking into consideration of their less maturity to give accurate feedback to the questionnaire.

\section{Sample size and sampling}

Total 400 samples were collected from five study sites on the basis of following formula:

$$
n=z^{2} p(1-p) / d^{2}
$$

All data were collected applying simple random sampling.

\section{Data collection}

Categorization of the OTC or POM medications was based on the University of Maryland Health Partners (UMHP) OTC Drug List (updated on May 2018) [21] and verified with the Nepalese Drug Act 1978 [22]. (Annex 1) Medicines prescribed were classified according to the ATC (Anatomic Therapeutic Chemical) classification proposed by the World Health Organization (WHO) [23]. (Annex 1) Self-developed semi-structured questionnaire was used for data collection and was pretested with the help of Cronbach's alpha value. Data were collected by four researchers of the team. The questionnaire was developed based on extensive literature reviews. The participants were interviewed about their awareness about medicine disposal techniques and their possible hazards and their willingness to support the take-back program, if introduced in their community. Pilot testing of the questionnaire was done in similar setting among $10 \%$ of the total sample size (i.e., 40) but with different participants. The questionnaires filled were processed and entered into the MS Excel and were analyzed by R 4.0.1 [24].

\section{Statistical analysis}

Descriptive analysis was done in terms of frequency distribution and percentage. Multinomial logistic regression analysis was applied to explore the relationship of health hazards, awareness of harm to the environment by inappropriate disposal, and willingness to follow take-back program with various predictor variables. The $p$-value less than 0.05 was considered statistically significant at $95 \%$ confidence level.

\section{Results}

The results showed that $30.3 \%$ respondents were between age group 16-25. Male respondents in the survey were $55.3 \% .28 .7 \%$ respondents were students (Table 1). 78.5\% respondents disposed UUE medicines with the household rubbish. $37.5 \%$ disposed the unused medication in garbage (Fig. 1 and 2 ). 
The multinomial logistic regression analysis showed that there was significant relationship of health hazards (rashes and diarrhea) among the farmers, engineers, nurse and lawyers ( $p$ value $<0.01$ in each). Headache, sleepiness was significant related with all the disposal practice i.e., in sinks, given to others, return to pharmacy, with rubbish and burn ( $p$ value $<0.01$ in each). (Table 2) Another multinomial logistic regression analysis showed that land pollution and effect on health of children was significantly related with the inappropriate disposal of medicines such as site of disposal ( $p$ value $<0.01)$, river ( $p$ value 0.02 ), garbage ( $p$ value 0.04$)$, and dumping site ( $p$ value 0.01$)$. (Table 3 )

The analysis of the willingness to follow take-back program with the techniques of support showed significant relationship with the establishment of collection center and participation on seminar ( $p$ value $<0.01$ ). (Table 4) Details of the medicines taken by the respondents as per their anatomic, therapeutic and chemical (ATC) classification and their POM or OTC category are shown in Annex 1. (Annex 1)

\section{Discussion}

The drug take-back program (DTP), despite being eco-friendly strategy to manage the UUE medications, is underutilized in many countries [18]. The study aimed to evaluate the willingness of the community people, residing at different locations of five districts of Nepal, towards the safe disposal of the UUE medicines to track the feasibility of the implementation of take-back program in their communities. 400 participants responded to the study, most of whom were youth (30.3\%) from the age group 16-25. Previously, Owens et al. reported that habit of throwing medications in household garbage was decreased with the increasing age [25]. Males were more inclined to dispose UUE medicines in the present research, which was contrast to that reported by Owens et al., who reported that more females flushed UUE medications down the toilet or sink [25]. Whatever be the gender, there is rising tendency of disposal of pharmaceuticals in garbage and sewer is in many countries [18].

The present research revealed that community people were discarding their UUE medicines with the household rubbish (78.5\%), down the sink (12\%), return to pharmacy (3.5\%), down the toilet (2.5\%), giving others (2.3\%). Similarly, $10 \%$ respondents flushed expired medicines down the toilet or sink in Afghanistan, Kuwait, Kenya, Ethiopia, UK and USA [7-11]. More than two-third respondents threw the UUE medicines in garbage (37.5\%) and dumping site (33\%). Abruquah et al. also found that $29 \%$ residents of Konongo-Odumasi in the Ashanti region of Ghana also threw such medicines into waste bin. Also, $38 \%$ buried in the ground, $4 \%$ flushed them down the toilet or sink and $21 \%$ had the intentions to transfer them to their relatives and friends [19]. El-Hamamsy found that $97 \%$ people out of 316 in 20 community pharmacies in Cairo, Egypt had some pharmaceuticals in their houses, $22.78 \%$ kept them till expiration date, $11.39 \%$ did not dispose them, $26.27 \%$ discarded them in household waste, $12 \%$ returned the UUE medications to the pharmacy and $11.39 \%$ flushed them in the toilet. The researcher suggested that community pharmacies have provision of adequate experts and storage area to collect and store unused medicines [26].

There was lack of dissemination of sufficient information regarding proper disposal techniques from the healthcare professionals to the community people. This was in line with the findings of Tong et al. who reported that community people had lack of knowledge and awareness regarding proper disposal of unused medicines and adverse effects of improper disposal method to the environment (Tong et al., 2011).Unsafe drug storage and disposal habits may pose the community people at risk of accidental poisoning, drug abuse, financial burden, improper recommendation and donation to neighbors, as well as environmental impact causing soil, water pollution affecting aquatic animals [5, 8, 11, 12,27]. Renal failure may occur among vultures following the ingestion of carcass from cattle treated with diclofenac. Similarly, antibiotics in water may lead to antibiotic resistance, genetic alterations in humans and marine life on long-term basis [7, 9]. Kinobe et al. reported that more than one-fourth of the respondents preferred mass media as the best source of improving awareness about disposal technique and implementing medicine take-back concept at Rawang, Malaysia [28].

A survey conducted in Ghana showed that $21 \%$ respondents passed the unwanted and unused medications to their close relatives and friends for future use thinking that they might be of use to them [18]. Results from the present study also revealed that $9.8 \%$ respondents passed the UUE medicines to their relatives and friends. Such results might be due to the lack of information regarding the negative impact of these to their health.

Results from this study revealed that $97.8 \%$ people were interested to support the medicine take-back programs, if implemented in their community. Lystlund et al. conducted a research at University of Oklahoma Family Medicine Department and found that $61 \%$ of patients reported interests on drug take-back programs. They found that the common UUE medicines handling activities were disposing in garbage (53.2\%) or sewer (29\%) and home storage (17.7\%). They concluded that the program would be more successful, if offered to the patients free of cost [3]. Previously, local residents were allowed to drop off UUE medicines free of cost in the Unwanted Medications Take Back Program initiated by Clark County (Washington) in 2003, provided that the medicine was not a controlled drug, was in the original and sealed container without breakage and leakage. This program was supported by 70 local pharmacies to safely dispose of unwanted or expired medicines and provided service daily and could collect 23 pounds of controlled drugs till 2006 [15].

Provision of adequate collection bags was perceived by the community people to be one of the major initiatives for the successful implementation of the takeback programs $[3,17,29]$. In Saudi Arabia, Ministry of Health issued an act in 1999 and the Gulf Countries Council (GCC) in 2001 regulated the management of the medical waste including unwanted pharmaceuticals. However, these acts could not optimize the proper disposal of leftover and expired medications due to the absence of medicine take-back programs. Therefore, urgency in improving general public knowledge and practice toward discarding medicine and assessing the level of awareness about the environmental risk through inappropriate medicine disposal was realized [30].

\section{Feasibility of implementation}

Extended Producer Responsibility campaign was proposed in Sweden in 1990 to make the pharmaceutical manufacturers responsible for the safe disposal of the environmentally harmful products. However, manufacturers were continually demanding that whole supply chain be tracked to trap the safe disposal. Later on, the US Supreme Court also mandated the industry-funded take-back programs for pharmaceuticals in the USA. However, the take-back programs got materialized into real practice only since 2016, although some efforts were already underway [31]. The present research found that the community people were interested to support the medicine take-back concept, if implemented in their community. However, main constraint was the budget and there was no 
data related to cost (both direct and indirect) of waste disposal via different technique based on the nature of the UUE medicines. Relying on the World Bank data, estimated cost of solid waste management was USD 1.5 billion in 2010 and would be increased to USD 7.7 billion in 2025 . The estimated cost for collection and disposal with waste generation rate of 0.22 ton per year and collection efficiency of $43 \%$ was $20-50$ USD per ton, 10-30 USD per ton for sanitary landfill, 2-8 USD per ton for open dumping and 5-30 USD per ton for composting in low income countries [32]. Previously, the city of Chicago had started its take-back program in 2003 on annual one-day collection basis at 25 locations and collected 7,000 pounds of waste medicines till the end of 2009 . The program was financed with USD 50,000 by the state [15]. Unfortunately, neither the Federal Government nor the Provincial Governments in Nepal have yet allocated budget for the implementation of the medicine take-back in Nepal. These all showed that the take-back concept could be initiated and implemented on the funding of the government or other external sources or from fund-raising from within the community members.

\section{Economic implications and sustainability of implementation of take-back concept:}

Viability of medicine take-back concept are far more compromised due to the rising cost of the returned medicines along with their procedural or administrative, and inventory holding costs, as well as due to the rising cost incurred in their safe disposal. Introducing of new concept including take-back or brown bag system itself demands some investment, and more than this, its sustainable operation demands a lot dedication, commitment from the concerned health care providers and policy makers. Bearing sustainability is mind, New Zealand introduced the copayment mechanism whereby each patient pays NZD $\$ 0$ or $\$ 3$ per item returned depending on his/her socioeconomic and health status, and number of items collected annually [2].

\section{Strengths And Limitations Of The Study}

- The results of the study concluded that public awareness program on appropriate disposal of UUE medicines was imperative and urgently needed.

- The results might offer insight toward optimizing the current scenario of disposal of the UUE medicines and awareness among the respondents regarding the impact of improper disposal.

- Presence of medications with scratched and label-less medicines in household setting made it difficult to recognize those unused medicines.

- The World Bank data related to cost of solid waste management might not be exactly applicable to the Nepalese setting. So, cost-wise feasibility of the implementation of medicine take-back concept in Nepal is still to be researched in a large scale.

- Budgetary constraint was the main hindrance for the same and the government should have invested for the service.

\section{Conclusions}

The study showed that majority of the participants kept the unused medications in their home, disposed them along with household rubbish and flushed down the sink or toilet which might pose risks to environment and human health. They were interested to support the medicine take-back concept, if implemented in their community but the main constraint was the budget. Hence, take-back concept could be initiated and implemented on the funding of the government or other external sources or from fund-raising from within the community members. Establishment of UUE medicines collection centers and distribution of plastic bags might be the appropriate disposal modality for the disposal of unused medicines in the community level.

\section{List Of Abbreviations}

ACEPD: Alachua County Environmental Protection Department

ATC: anatomic, therapeutic and chemical

DTP: drug take-back program

DUMP: Disposal of Unwanted Medication Properly

GCC: Gulf Countries Council

HCFs: healthcare facilities

ONDCP: Office of National Drug Control Policy

OTC: over-the-counter

POM: prescription-only medicine

PUIRC: Pokhara University Institutional Review Committee

UMHP: University of Maryland Health Partners

UUE: unwanted, unused and expired

WHO: World Health Organization

\section{Declarations}


Ethics approval and consent to participate

Ethics approval was taken from Pokhara University Institutional Review Committee (PUIRC), Kaski, Nepal (109/074/75).

\section{Consent for publication}

Not applicable

\section{Availability of data and material}

All data supporting the findings of this study are contained within the manuscript. Any additional information regarding the study including the questionnaires will be shared by the corresponding author upon request.

\section{Competing interests}

The authors declare that they have no competing interests.

\section{Funding}

This research was supported by the Pokhara University Faculty Research Grant. No funding bodies had any role in study design, data collection and analysis, decision to publish, or preparation of the manuscript.

\section{Authors' contributions}

BS conceptualized and designed the study, performed literature review, analyzed and interpreted data, and prepared the final manuscript. AG designed the study, performed literature review, and drafted the manuscript. BB, KA, KB, and BJ collected data, performed fieldworks including training to the public about medication for the research, performed literature review, drafted and revised the manuscript. KRJ contributed in project administration, validation, drafting and revising the manuscript. All authors read and approved the final manuscript.

\section{Acknowledgements}

The authors would like to express their gratitude to all the participants for their cooperation in the research.

\section{References}

1. Simons TE. Drug Take-back Programs: Safe Disposal of Unused, Expired, or Unwanted Medications in North Carolina. Coastal Coalition for Substance Abuse Prevention 2010:1-17.

2. James TH, Helms ML, Braund R. Analysis of Medications Returned to Community Pharmacies. The Annals of Pharmacotherapy 2009;43:1631-5.

3. Lystlund S, Stevens E, Planas LG, Marcy TR. Patient participation in a clinic-based community pharmacy medication take-back program. J Am Pharm Assoc. 2014;54:280-284.

4. Tong AYC, Peake BM, Braund R. Disposal practices for unused medications around the world. Environmental International 2011;37:292-98.

5. Law AV, Sakharkar P, Zargarzadeh A, Tai BWB, Hess K, Hata M, Mireles R, Ha C, Park TJ. Taking stock of medication wastage: Unused medications in US households. Research in Social and Administrative Pharmacy 2015;11:571-578.

6. Brown T. Implications for a Drug Take Back Program in the Veterans Affairs Healthcare System (Thesis). North Carolina State University $2014: 1-29$.

7. Angi'enda SA, Bukachi SA. Household Knowledge and Perceptions on Disposal Practices of Unused Medicines in Kenya. Journal of Anthropology and Archeology 2016;4(2):1-20.

8. Atinafu T, Takele A, Kassie A, Yehualaw A, Tesfaw G, Desseno T, Mekonnen T, Fentie M. Unused Medications Disposal Practice: The case of Patients Visiting University of Gondar Specialized Teaching Hospital, Gondar, Ethiopia. International Journal of Pharma Sciences and Research 2014;5(12):9991005.

9. Bashaar M, Thawani V, Hassali MA, Saleem F. Disposal practices of unused and expiredpharmaceuticals among general public in Kabul. BMC Public Health 2017;17:45. doi: 10.1186/s12889-016-3975-z.

10. Crawford BC, Ng R. Update on the Safe Drug Disposal/Pharmaceutical Return Program. Community Development Agency Environmental Health Services Division. Marin County Civic Center. 2015. Retrieved from https://www.marincounty.org/ /media/files/maringov/board-

actions/2017/october/1710038cdasafedrugltr.pdf?la=en and http://marin.granicus.com/MetaViewer.php?view_id=36\&clip_id=7679\&meta_id=801582 on November 15, 2017.

11. Patil SS, Patil SK. Critical eye towards storage and disposal of prescribed medicine. Global Journal of Medicine and Public Health 2013;2(6):1-5.

12. Siler S, Duda S, Brown R, Gbemudu J, Weier S, Glaudemans J. Safe Disposal of Unused Controlled Substances: Current Challenges and Opportunities for Reform 2008:8-69.

13. Thach AV, Brown CM, Pope N. Consumer perceptions about a community pharmacy-based medication take back program. Journal of Environmental Management 2013;127:23-27.

14. Yang CHJ, Doshi M, Mason NA. Analysis of Medications Returned During a Medication Take-Back Event. Pharmacy 2015;3:79-88.

15. Illinois-Indiana Sea Grant resource kit. Disposal of Unwanted Medicines: A Resource for Action in Your Community 2009:1-61. 
16. Smolen A. Role of the Pharmacist in Proper Medication Disposal. US Pharm. 2011;36(7):52-55.

17. Yeh BT. Legal Issues Relating to the Disposal of Dispensed Controlled Substances. Congressional Research Service (CRS) Report for Congress 2010:1-14.

18. Alnahas F, Yeboah P, Fliedel L, Abdin AY, Alhareth K. Expired Medication: Societal, Regulatory and Ethical Aspects of a Wasted Opportunity. Int. J. Environ. Res. Public Health 2020;17:787. doi:10.3390/ijerph17030787.

19. Abruquah AA, Drewry JA, Ampratwum FT. What happens to unused, expired and unwanted medications? A survey of a community- based medication disposal practices. International Journal of Development and Sustainability 2014;3(12):2175-85.

20. NPHC 2011. National Population and Housing Census 2011 (National Report). Government of Nepal Central Bureau of Statistics, Kathmandu, Nepal. Extracted from https://unstats.un.org/unsd/demographic-social/census/documents/Nepal/Nepal-Census-2011-Vol1.pdf on July 25, 2017.

21. UMHP. Over-the-Counter Drug List. University of Maryland Health Partners (UMHP). Retrieved from https://www.umhealthpartners.com/wpcontent/uploads/2016/09/Over-The-Counter-OTC-Drug-List-May-1-2018.pdf on September 20, 2018.

22. DDA. Drugs Act, 2035, (1978). Government of Nepal Department of Drug Administration. Retrieved fromhttp://www.dda.gov.np/content/drugs-act-2035 on June $15,2018$.

23. WHO. WHO Guidelines for ATC classification and DDD assignment $202023^{\text {rd }}$ edition. WHO Collaborating Centre for Drug Statistics Methodology. Oslo, Norway 2019: 10-247.

24. R Core Team. R: A language and environment for statistical computing. R Foundation for Statistical Computing, Vienna, Austria, 2020. https://www.Rproject.org/

25. Owens L, Anand S. Medication Disposal Survey. University of Illinois at Chicago 2009:1-18.

26. El-Hamamsy M. Unused medications: How cost and how disposal of in Cairo, Egypt. International Journal of Pharmaceutical Studies and Research 2011;II(I):21-27.

27. ISMP Canada. Safe Storage and Disposal of Medications. Institute for Safe Medication Practices Canada 2018;18(5):1-6. Retrieved from www.ismpcanada.org/err_index.htm on September 16, 2018.

28. Kinobe JR, Gebresenbet G, Vinneras B. Reverse Logistics Related to Waste Management with Emphasis on Developing Countries-A Review Paper. Journal of Environmental Science and Engineering 2012:1104-1118.

29. Azad MAK, Ansary MRH, Akhter MA, Al-Mamun SMM, Uddin M, Rahman MM. Disposal Practice for Unused Medications among the Students of the International Islamic University, Malaysia. Journal of Applied Pharmaceutical Science 2012;2(7):101-106.

30. Abdallah QMA, Al-Haddad MSM, Al-Khathami OHM, Al-Kherish OHH, Al-Marri KMT, Al-Matani MFK, Al-Rashed AMN. Knowledge, Attitude and Practice towards discarding unwanted household medicines among University Students in Western Region, KSA. Int J Pharm 2014;4(4):14-21.

31. Hochman ME. Disposing of Unused Medications: Have We Been Doing It All Wrong? [Commentary] The American Journal of Medicine 2017;130(2):115-6. 32. World Bank. What a Waste: A Global Review of Solid Waste Management. World Bank's Urban Development and Local Government Unit 2012;15:1-98.

\section{Tables}

Table 1. Demographic characteristics of the respondents $(n=400)$ 


\begin{tabular}{|c|c|}
\hline Study variables & Frequency $(\%)$ \\
\hline \multicolumn{2}{|c|}{ Age of respondents (in years) (Mean $\pm S D$ : $34.74 \pm 12.753$ ) } \\
\hline $16-25$ & $121(30.3)$ \\
\hline $26-35$ & $117(29.3)$ \\
\hline $36-45$ & $78(19.5)$ \\
\hline $46-55$ & $51(12.8)$ \\
\hline $56-65$ & $27(6.8)$ \\
\hline $66+$ & $6(1.5)$ \\
\hline \multicolumn{2}{|c|}{ Gender of the respondents } \\
\hline Male & $221(55.3)$ \\
\hline Female & $179(44.8)$ \\
\hline \multicolumn{2}{|c|}{ Address of the respondents } \\
\hline Mahendranagar & $100(25)$ \\
\hline Dhangadhi & $100(25)$ \\
\hline Kathmandu & $69(17.25)$ \\
\hline Lalitpur & $31(7.75)$ \\
\hline Pokhara & $100(25)$ \\
\hline \multicolumn{2}{|c|}{ Profession of the respondents } \\
\hline Housewife & $80(20)$ \\
\hline Businessman & $71(17.8)$ \\
\hline Worker & $64(16)$ \\
\hline Student & $115(28.7)$ \\
\hline Teacher & $41(10.3)$ \\
\hline Farmer & $12(3)$ \\
\hline Engineer & $4(1)$ \\
\hline Nurse & $3(0.8)$ \\
\hline Bank Manager & $6(1.5)$ \\
\hline Lawyer & $4(1)$ \\
\hline
\end{tabular}

Table 2. Multinomial logistic regression analysis of health hazards with various predictor variables 


\begin{tabular}{|c|c|c|c|c|c|c|c|c|c|c|c|c|}
\hline \multirow[t]{3}{*}{ Predictors } & \multicolumn{12}{|c|}{ Health hazards experienced by the respondents } \\
\hline & \multicolumn{3}{|c|}{ Rashes and diarrhea } & \multicolumn{3}{|c|}{ Irritation, headache, unable to walk } & \multicolumn{3}{|c|}{ Headache, sleepiness } & \multicolumn{3}{|c|}{$\begin{array}{l}\text { Blurring of eyes; leg anc } \\
\text { weaknesses }\end{array}$} \\
\hline & $\begin{array}{l}\text { Beta } \\
\text { (SE) }\end{array}$ & $\begin{array}{l}\mathrm{p}- \\
\text { value }\end{array}$ & $\begin{array}{l}95 \% \mathrm{Cl} \text { for } \\
\text { OR (L \& U) }\end{array}$ & $\begin{array}{l}\text { Beta } \\
\text { (SE) }\end{array}$ & $\begin{array}{l}\mathrm{p}- \\
\text { value }\end{array}$ & $\begin{array}{l}95 \% \mathrm{Cl} \text { for } \\
\text { OR }(L \& U)\end{array}$ & $\begin{array}{l}\text { Beta } \\
\text { (SE) }\end{array}$ & p-value & $\begin{array}{l}95 \% \mathrm{Cl} \text { for OR } \\
(\mathrm{L} \& \mathrm{U})\end{array}$ & Beta (SE) & $\begin{array}{l}\mathrm{p}- \\
\text { value }\end{array}$ & $\begin{array}{l}9 \\
(\mathrm{~L}\end{array}$ \\
\hline Intercept & $\begin{array}{l}-4.1 \\
(1.77)\end{array}$ & 0.02 & $\begin{array}{l}0.01 \\
\left(5.1^{*} 10-4\right. \\
0.53)\end{array}$ & $\begin{array}{l}2.32 \\
(3.64)\end{array}$ & 0.52 & $\begin{array}{l}2.77(0.01 \\
70.43)\end{array}$ & $\begin{array}{l}-12.18 \\
(1.82)\end{array}$ & $\begin{array}{l}2.65^{\star} 10- \\
11\end{array}$ & $\begin{array}{l}5.08 * 10- \\
6(1.41 * 10-7 \\
1.83 * 10-4)\end{array}$ & $\begin{array}{l}-15.24 \\
(19.57)\end{array}$ & 0.43 & $\begin{array}{l}2 . \\
71 \\
2\end{array}$ \\
\hline Age & $\begin{array}{l}0.03 \\
(0.02)\end{array}$ & 0.2 & $\begin{array}{l}1.03(0.98 \\
1.08)\end{array}$ & $\begin{array}{l}0.01 \\
(0.05)\end{array}$ & 0.89 & $\begin{array}{l}1.01(0.91 \\
1.11)\end{array}$ & $\begin{array}{l}-0.02 \\
(0.05)\end{array}$ & 0.69 & $\begin{array}{l}0.97(0.87 \\
1.09)\end{array}$ & $\begin{array}{l}-0.03 \\
(0.09)\end{array}$ & 0.67 & 0 . \\
\hline $\begin{array}{l}\text { Gender } \\
\text { (Female) }\end{array}$ & $\begin{array}{l}0.77 \\
(0.58)\end{array}$ & 0.18 & $\begin{array}{l}2.17(0.69 \\
6.82)\end{array}$ & $\begin{array}{l}-1.65 \\
(1.7)\end{array}$ & 0.33 & $\begin{array}{l}0.19(0.01 \\
5.38)\end{array}$ & $\begin{array}{l}1.93 \\
(1.24)\end{array}$ & 0.12 & $\begin{array}{l}6.9(0.6 \\
21.47)\end{array}$ & $\begin{array}{l}6.84 \\
(29.47)\end{array}$ & 0.81 & $\begin{array}{l}6 ! \\
2:\end{array}$ \\
\hline \multicolumn{13}{|l|}{ Profession } \\
\hline Businessman & $\begin{array}{l}1.79 \\
(0.96)\end{array}$ & 0.06 & $\begin{array}{l}\text { 6.02(0.9 } \\
10.92)\end{array}$ & $\begin{array}{l}-3.65 \\
(2.82)\end{array}$ & 0.19 & $\begin{array}{l}0.02(1.01 * 10- \\
4,6.6)\end{array}$ & $\begin{array}{l}1.61 \\
(1.51)\end{array}$ & 0.28 & $\begin{array}{l}5(0.25 \\
26.36)\end{array}$ & $\begin{array}{l}-5.72 \\
(0.1)\end{array}$ & $<0.01$ & $\begin{array}{l}0 . \\
0 .\end{array}$ \\
\hline Worker & $\begin{array}{l}1.14 \\
(1.05)\end{array}$ & 0.27 & $\begin{array}{l}3.15(0.39 \\
6.76)\end{array}$ & $\begin{array}{l}-11.99 \\
(0.01)\end{array}$ & $<0.01$ & $\begin{array}{l}6.2 * 10- \\
6\left(6.18^{*} 10-6\right. \\
\left.6.22^{*} 10-6\right)\end{array}$ & $\begin{array}{l}1.37 \\
(1.6)\end{array}$ & 0.39 & $\begin{array}{l}3.95(0.17 \\
24.89)\end{array}$ & $\begin{array}{l}-6.81 \\
(0.06)\end{array}$ & $<0.01$ & $\begin{array}{l}0 \\
4\end{array}$ \\
\hline Student & $\begin{array}{l}1.46 \\
(1.06)\end{array}$ & 0.16 & $\begin{array}{l}4.32(0.53 \\
9.43)\end{array}$ & $\begin{array}{l}-2.07 \\
(1.96)\end{array}$ & 0.29 & $\begin{array}{l}0.12(0.01 \\
5.89)\end{array}$ & $\begin{array}{l}0.05 \\
(1.69)\end{array}$ & 0.97 & $\begin{array}{l}1.05(0.03 \\
8.04)\end{array}$ & $\begin{array}{l}-0.24 \\
(2.01)\end{array}$ & 0.9 & $\begin{array}{l}0 . \\
11\end{array}$ \\
\hline Teacher & $\begin{array}{l}0.33 \\
(1.29)\end{array}$ & 0.79 & $\begin{array}{l}1.39(0.1 \\
4.78)\end{array}$ & $\begin{array}{l}-13.79 \\
(8.11 * 10- \\
5)\end{array}$ & $<0.01$ & $\begin{array}{l}1.01 * 10- \\
6(1.01 * 10-6 \\
1.01 * 10-6)\end{array}$ & $\begin{array}{l}1.25 \\
(1.52)\end{array}$ & 0.41 & $\begin{array}{l}3.51(0.17 \\
19.08)\end{array}$ & $\begin{array}{l}-8.93 \\
(0.01)\end{array}$ & $<0.01$ & $\begin{array}{l}1 . \\
41 \\
1 .\end{array}$ \\
\hline Farmer & $\begin{array}{l}-9.93 \\
(6.82 * 10- \\
5)\end{array}$ & $<0.01$ & $\begin{array}{l}4.85 * 10- \\
5\left(4.85^{*} 10-\right. \\
5, \\
4.85 * 10- \\
5)\end{array}$ & $\begin{array}{l}-14.78 \\
\left(6.68^{*} 10-\right. \\
6)\end{array}$ & $<0.01$ & $\begin{array}{l}3.79 * 10- \\
7(3.79 * 10-7, \\
3.79 * 10-7)\end{array}$ & $\begin{array}{l}-8.76 \\
(2.98 * 10- \\
5)\end{array}$ & $<0.01$ & $\begin{array}{l}1.56 * 10- \\
4(1.56 * 10-4 \\
1.56 * 10-4)\end{array}$ & $\begin{array}{l}-11.23 \\
\left(1.3^{\star} 10-\right. \\
4)\end{array}$ & $<0.01$ & $\begin{array}{l}1 . \\
51 \\
1 .\end{array}$ \\
\hline Engineer & $\begin{array}{l}-9.43 \\
(5.38 * 10- \\
5)\end{array}$ & $<0.01$ & $\begin{array}{l}8^{*} 10- \\
5\left(8^{*} 10-5\right. \\
\left.8^{*} 10-5\right)\end{array}$ & $\begin{array}{l}-22.12 \\
(2.54 * 10- \\
7)\end{array}$ & $<0.01$ & $\begin{array}{l}2.45^{\star} 10- \\
10\left(2.45^{*} 10-\right. \\
10,2.45^{\star} 10- \\
10)\end{array}$ & $\begin{array}{l}-4.92 \\
(9.11 * 10- \\
4)\end{array}$ & $<0.01$ & $\begin{array}{l}0.01(0.01 \\
0.01)\end{array}$ & $\begin{array}{l}-0.59 \\
(0.89)\end{array}$ & 0.5 & $\begin{array}{l}0 . \\
3 .\end{array}$ \\
\hline Nurse & $\begin{array}{l}-8.01 \\
(4.62 * 10- \\
5)\end{array}$ & $<0.01$ & $\begin{array}{l}3.34 * 10- \\
43.34 * 10- \\
4, \\
3.34 * 10- \\
4)\end{array}$ & $\begin{array}{l}-9.49 \\
(2.01 * 10- \\
5)\end{array}$ & $<0.01$ & $\begin{array}{l}7.54 * 10- \\
5(7.54 * 10-5 \\
7.54 * 10-5)\end{array}$ & $\begin{array}{l}-7.59 \\
(2.25 \star 10- \\
4)\end{array}$ & $<0.01$ & $\begin{array}{l}5.02 * 10- \\
4(5.02 * 10-4 \\
5.03 * 10-4)\end{array}$ & $\begin{array}{l}-7.44 \\
(0.01)\end{array}$ & $<0.01$ & $\begin{array}{l}5 . \\
41 \\
5 .\end{array}$ \\
\hline $\begin{array}{l}\text { Bank } \\
\text { Manager }\end{array}$ & $\begin{array}{l}1.74 \\
(1.65)\end{array}$ & 0.29 & $\begin{array}{l}5.71(0.22 \\
10.78)\end{array}$ & $\begin{array}{l}-22.03 \\
\left(4.35^{\star} 10-\right. \\
7)\end{array}$ & $<0.01$ & $\begin{array}{l}2.7 * 10- \\
10(2.7 * 10-10 \\
2.7 * 10-10)\end{array}$ & $\begin{array}{l}-6.41 \\
(4.05 \star 10- \\
4)\end{array}$ & $<0.01$ & $\begin{array}{l}0.01(0.01 \\
0.01)\end{array}$ & $\begin{array}{l}-6.59 \\
(0.01)\end{array}$ & $<0.01$ & $\begin{array}{l}0 . \\
0 .\end{array}$ \\
\hline Lawyer & $\begin{array}{l}-9.34 \\
(1.91 * 10- \\
5)\end{array}$ & $<0.01$ & $\begin{array}{l}8.76 * 10- \\
5(8.76 * 10- \\
5, \\
8.76 * 10- \\
5)\end{array}$ & $\begin{array}{l}-16.14 \\
\left(2.63^{*} 10-\right. \\
6)\end{array}$ & $<0.01$ & $\begin{array}{l}9.7 * 10- \\
8(9.7 * 10-8, \\
9.7 * 10-8)\end{array}$ & $\begin{array}{l}-3.49 \\
(7.67 * 10- \\
4 \stackrel{)}{)}\end{array}$ & $<0.01$ & $\begin{array}{l}0.03(0.03 \\
0.03)\end{array}$ & $\begin{array}{l}-0.17 \\
(0.42)\end{array}$ & 0.67 & $\begin{array}{l}0 . \\
1 .\end{array}$ \\
\hline \multicolumn{13}{|l|}{$\begin{array}{l}\text { Medicines } \\
\text { disposed }\end{array}$} \\
\hline Sink & $\begin{array}{l}-2.43 \\
(1.44)\end{array}$ & 0.09 & $\begin{array}{l}0.08(0.01 \\
1.47)\end{array}$ & $\begin{array}{l}-3.71 \\
(2.16)\end{array}$ & 0.08 & $\begin{array}{l}0.02(3.51 * 10- \\
4,1.69)\end{array}$ & $\begin{array}{l}-6.2 \\
(1.37 * 10- \\
5)\end{array}$ & $<0.01$ & $\begin{array}{l}0.01(0.01 \\
0.01)\end{array}$ & $\begin{array}{l}-5.75 \\
(0.03)\end{array}$ & $<0.01$ & $\begin{array}{l}0 . \\
0 .\end{array}$ \\
\hline $\begin{array}{l}\text { Giving to } \\
\text { others }\end{array}$ & $\begin{array}{l}-0.73 \\
(1.54)\end{array}$ & 0.63 & $\begin{array}{l}0.48(0.02, \\
9.89)\end{array}$ & $\begin{array}{l}-15.24 \\
(7.79 * 10- \\
6)\end{array}$ & $<0.01$ & $\begin{array}{l}2.4 * 10- \\
7\left(2.4^{*} 10-7\right. \\
2.4 * 10-7)\end{array}$ & $\begin{array}{l}-4.37 \\
(3.78 * 10- \\
5)\end{array}$ & $<0.01$ & $\begin{array}{l}0.01(0.02, \\
0.02)\end{array}$ & $\begin{array}{l}-1.23 \\
(9.65 * 10- \\
4)\end{array}$ & $<0.01$ & $\begin{array}{l}0 . \\
0 .\end{array}$ \\
\hline $\begin{array}{l}\text { Return to } \\
\text { pharmacy }\end{array}$ & $\begin{array}{l}-0.2 \\
(1.32)\end{array}$ & 0.87 & $\begin{array}{l}0.81(0.06 \\
2.96)\end{array}$ & $\begin{array}{l}-17.07 \\
(1.77 * 10- \\
5)\end{array}$ & $<0.01$ & $\begin{array}{l}3.85^{*} 10- \\
8\left(3.85^{\star} 10-8\right. \\
\left.3.85^{*} 10-8\right)\end{array}$ & $\begin{array}{l}-3.83 \\
(4.34 * 10- \\
5)\end{array}$ & $<0.01$ & $\begin{array}{l}0.02(0.02 \\
0.02)\end{array}$ & $\begin{array}{l}8.22 \\
(2.74)\end{array}$ & 0.41 & $\begin{array}{l}7 ! \\
6,\end{array}$ \\
\hline With rubbish & $\begin{array}{l}-1.65 \\
(1.05)\end{array}$ & 0.11 & $\begin{array}{l}0.19(0.02, \\
1.51)\end{array}$ & $\begin{array}{l}-4.92 \\
(2.13)\end{array}$ & 0.02 & $\begin{array}{l}0.01(1.11 * 10- \\
4,0.47)\end{array}$ & $\begin{array}{l}6.87 \\
(1.18)\end{array}$ & $\begin{array}{l}6.95^{\star} 10- \\
9\end{array}$ & $\begin{array}{l}71.15(25.6, \\
197.6)\end{array}$ & $\begin{array}{l}5.07 \\
(10.13)\end{array}$ & 0.61 & $\begin{array}{l}1 \\
7,\end{array}$ \\
\hline Burn & $\begin{array}{l}-11.15 \\
(5.31 * 10- \\
5)\end{array}$ & $<0.01$ & $\begin{array}{l}1.42 * 10- \\
5(1.42 * 10- \\
5\end{array}$ & $\begin{array}{l}-18.55 \\
(1.84 * 10- \\
6)\end{array}$ & $<0.01$ & $\begin{array}{l}8.75^{\star} 10- \\
9\left(8.75^{\star} 10-9,\right. \\
\left.8.75^{\star} 10-9\right)\end{array}$ & $\begin{array}{l}8.91 \\
(1.16)\end{array}$ & $\begin{array}{l}2.33^{*} 10- \\
14\end{array}$ & $\begin{array}{l}\text { 149.83(55.78, } \\
402.38)\end{array}$ & $\begin{array}{l}-5.79 \\
(0.01)\end{array}$ & $<0.01$ & $\begin{array}{l}0 . \\
0 .\end{array}$ \\
\hline
\end{tabular}


Table 3.Multinomial logistic regression analysis of awareness of harm to the environment by inappropriate disposal with the site of disposal

\begin{tabular}{|c|c|c|c|c|c|c|c|c|c|c|c|c|c|c|}
\hline \multirow{3}{*}{$\begin{array}{l}\text { Predictors } \\
\text { Site of } \\
\text { disposal }\end{array}$} & \multicolumn{14}{|c|}{ Inappropriate disposal of medicines and harm to the environment } \\
\hline & \multicolumn{3}{|c|}{$\begin{array}{l}\text { Causes land pollution, } \\
\text { affect health of children }\end{array}$} & \multicolumn{3}{|c|}{$\begin{array}{l}\text { Causes environment } \\
\text { pollution }\end{array}$} & \multicolumn{3}{|c|}{ Causes air pollution } & \multicolumn{3}{|c|}{ Affects children's health } & \multicolumn{2}{|c|}{ Causes water po } \\
\hline & $\begin{array}{l}\text { Beta } \\
\text { (SE) }\end{array}$ & p-value & $\begin{array}{l}95 \% \\
\text { Cl for } \\
\text { OR (L } \\
\& U)\end{array}$ & $\begin{array}{l}\text { Beta } \\
\text { (SE) }\end{array}$ & p-value & $\begin{array}{l}95 \% \\
\text { Cl for } \\
\text { OR (L } \\
\& U)\end{array}$ & $\begin{array}{l}\text { Beta } \\
\text { (SE) }\end{array}$ & p-value & $\begin{array}{l}95 \% \mathrm{Cl} \\
\text { for OR } \\
(\mathrm{L} \& U)\end{array}$ & $\begin{array}{l}\text { Beta } \\
\text { (SE) }\end{array}$ & p-value & $\begin{array}{l}95 \% \mathrm{Cl} \\
\text { for OR } \\
(L \& U)\end{array}$ & $\begin{array}{l}\text { Beta } \\
\text { (SE) }\end{array}$ & $\begin{array}{l}p- \\
\text { valu }\end{array}$ \\
\hline Intercept & $\begin{array}{l}-1.71 \\
(0.36)\end{array}$ & $\begin{array}{l}2.18 * 10- \\
6\end{array}$ & $\begin{array}{l}0.17 \\
(0.08, \\
0.36)\end{array}$ & $\begin{array}{l}-1.42 \\
(0.32)\end{array}$ & $\begin{array}{l}9.01 * 10- \\
6\end{array}$ & $\begin{array}{l}0.24 \\
(0.12 \\
0.45)\end{array}$ & $\begin{array}{l}-1.96 \\
(0.4)\end{array}$ & $\begin{array}{l}1.1 * 10- \\
6\end{array}$ & $\begin{array}{l}0.14 \\
(0.06 \\
0.3)\end{array}$ & $\begin{array}{l}-2.12 \\
(0.43)\end{array}$ & $\begin{array}{l}9.22 * 10- \\
7\end{array}$ & $\begin{array}{l}0.12 \\
(0.05 \\
0.27)\end{array}$ & $\begin{array}{l}-16.15 \\
(0.3)\end{array}$ & $<0 . C$ \\
\hline River & $\begin{array}{l}1.35 \\
(0.61)\end{array}$ & 0.02 & $\begin{array}{l}3.88 \\
(1.17 \\
12.89)\end{array}$ & $\begin{array}{l}0.73 \\
(0.63)\end{array}$ & 0.24 & $\begin{array}{l}2.08 \\
(0.59 \\
7.23)\end{array}$ & $\begin{array}{l}-0.33 \\
(1.12)\end{array}$ & 0.76 & $\begin{array}{l}0.71 \\
(0.07 \\
6.46)\end{array}$ & $\begin{array}{l}-0.18 \\
(1.13)\end{array}$ & 0.87 & $\begin{array}{l}0.83 \\
(0.09 \\
7.69)\end{array}$ & $\begin{array}{l}14.94 \\
(0.55)\end{array}$ & $<0 . C$ \\
\hline Garbage & $\begin{array}{l}0.89 \\
(0.44)\end{array}$ & 0.04 & $\begin{array}{l}2.45 \\
(1.03 \\
5.82)\end{array}$ & $\begin{array}{l}1.42 \\
(0.37)\end{array}$ & $<0.01$ & $\begin{array}{l}4.16 \\
(1.99 \\
8.71)\end{array}$ & $\begin{array}{l}-0.37 \\
(0.61)\end{array}$ & 0.54 & $\begin{array}{l}0.68 \\
(0.2, \\
2.3)\end{array}$ & $\begin{array}{l}0.94 \\
(0.51)\end{array}$ & 0.06 & $\begin{array}{l}2.56 \\
(0.92 \\
7.07)\end{array}$ & $\begin{array}{l}12.89 \\
(0.59)\end{array}$ & $<0 . C$ \\
\hline $\begin{array}{l}\text { Dumping } \\
\text { site }\end{array}$ & $\begin{array}{l}1.4 \\
(0.43)\end{array}$ & 0.01 & $\begin{array}{l}4.09 \\
(1.72 \\
9.68)\end{array}$ & $\begin{array}{l}1.59 \\
(0.38)\end{array}$ & $4.2 * 10-5$ & $\begin{array}{l}4.93 \\
(2.29 \\
10.59)\end{array}$ & $\begin{array}{l}0.27 \\
(0.57)\end{array}$ & 0.63 & $\begin{array}{l}1.31 \\
(0.42 \\
4.07)\end{array}$ & $\begin{array}{l}0.96 \\
(0.54)\end{array}$ & 0.07 & $\begin{array}{l}2.63 \\
(0.9 \\
7.64)\end{array}$ & $\begin{array}{l}13.2 \\
(0.59)\end{array}$ & $<0 . C$ \\
\hline Burn & $\begin{array}{l}1.71 \\
(1.45)\end{array}$ & 0.24 & $\begin{array}{l}5.55 \\
(0.31 \\
97.19)\end{array}$ & $\begin{array}{l}1.42 \\
(1.45)\end{array}$ & 0.32 & $\begin{array}{l}4.16 \\
(0.24 \\
71.54)\end{array}$ & $\begin{array}{l}3.06 \\
(1.22)\end{array}$ & 0.01 & $\begin{array}{l}21.43 \\
(1.94 \\
235.77)\end{array}$ & $\begin{array}{l}2.12 \\
(1.47)\end{array}$ & 0.15 & $\begin{array}{l}8.33 \\
(0.45, \\
151.29)\end{array}$ & $\begin{array}{l}-0.68 \\
(2.18 * 10- \\
7)\end{array}$ & $<0 . C$ \\
\hline
\end{tabular}

Table 4.Multinomial regression analysis of the willingness to follow take-back program with the techniques of support

\begin{tabular}{|c|c|c|c|c|c|c|}
\hline \multirow{3}{*}{$\begin{array}{l}\text { Predictors } \\
\text { Mode of following/supporting the program }\end{array}$} & \multicolumn{6}{|c|}{ Willingness to follow or support the take-back program } \\
\hline & \multicolumn{3}{|l|}{ Yes } & \multicolumn{3}{|l|}{ No idea } \\
\hline & Beta (SE) & p-value & $95 \% \mathrm{Cl}$ for OR (L \& U) & Beta (SE) & $\begin{array}{l}\mathrm{p}- \\
\text { value }\end{array}$ & $95 \% \mathrm{Cl}$ for OR ( $L \& \mathrm{U})$ \\
\hline Intercept & $-1.25(0.8)$ & 0.11 & $0.28(5.93,1.37)$ & $-1.94(1.06)$ & 0.06 & $0.14(0.01,1.16)$ \\
\hline $\begin{array}{l}\text { Providing knowledge about disposal method of } \\
\text { unused medicines }\end{array}$ & $\begin{array}{l}541.41 \\
(\mathrm{NaN})\end{array}$ & $\mathrm{NaN}$ & $1.35^{\star} 10^{235}(\mathrm{NaN}, \mathrm{NaN}$ & $-6.65(0)$ & $<0.01$ & $0.01(0.01,0.01)$ \\
\hline $\begin{array}{l}\text { Awareness program; Establishing collection } \\
\text { center }\end{array}$ & $\begin{array}{l}1092.27 \\
(\mathrm{NaN})\end{array}$ & $\mathrm{NaN}$ & $\operatorname{lnf}(\mathrm{NaN}, \mathrm{NaN})$ & $-6.16(0)$ & $<0.01$ & $0.01(0.01,0.01)$ \\
\hline $\begin{array}{l}\text { Participation in orientation program; Establishing } \\
\text { collection center }\end{array}$ & $\begin{array}{l}19.15 \\
(2183.65)\end{array}$ & 0.99 & $6230.2(0, \operatorname{lnf})$ & $-1.22(91.1)$ & 0.98 & $\begin{array}{l}0.29(8.19 * 10-79 \\
\left.1.04 * 10^{77}\right)\end{array}$ \\
\hline $\begin{array}{l}\text { Establishing collection center; Participating on } \\
\text { seminar }\end{array}$ & $\begin{array}{l}30.15 \\
(1.38 * 10-8)\end{array}$ & $<0.01$ & $\begin{array}{l}548592.6(548592.6 \\
548592.6)\end{array}$ & $\begin{array}{l}-1.92 \\
(2.43 * 10-10)\end{array}$ & $<0.01$ & $0.14(0.14,0.14)$ \\
\hline Establishing collection center & $5.34(1.28)$ & $\begin{array}{l}3.31 * 10- \\
5\end{array}$ & $15.51(4.56,52.62)$ & $\begin{array}{l}-196.44 \\
(1.9 * 10-84)\end{array}$ & $<0.01$ & $\begin{array}{l}4.86 * 10-86(4.86 * 10- \\
86,4.86 * 10-86)\end{array}$ \\
\hline Providing disposal bags; Awareness program & $\begin{array}{l}95.28 \\
(2.02 * 10-25)\end{array}$ & $<0.01$ & $\begin{array}{l}2.41 * 10^{41}\left(2.41 * 10^{41}\right. \\
\left.2.41 * 10^{41}\right)\end{array}$ & $\begin{array}{l}-3.44 \\
(5.06 * 10-39)\end{array}$ & $<0.01$ & $0.03(0.03,0.03)$ \\
\hline $\begin{array}{l}\text { Pharmacy should take-back unused medicines; } \\
\text { Arranging disposal site }\end{array}$ & $\begin{array}{l}17.72 \\
(2117.85)\end{array}$ & 0.99 & $5450.26(0, \operatorname{lnf})$ & $\begin{array}{l}-1.02 \\
(107.74)\end{array}$ & 0.99 & $\begin{array}{l}0.35\left(6.85^{\star} 10-93\right. \\
\left.1.85^{\star} 10^{91}\right)\end{array}$ \\
\hline
\end{tabular}

\section{Figures}


Disposal techniques for the unused and expired medicines

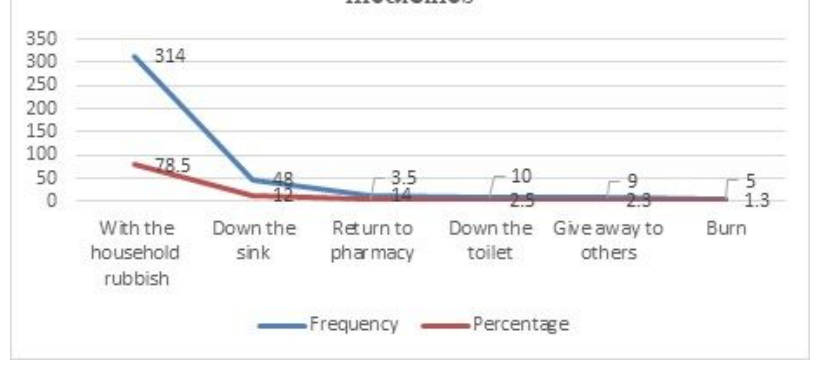

\section{Figure 1}

Disposal techniques for the unused and expired medicines

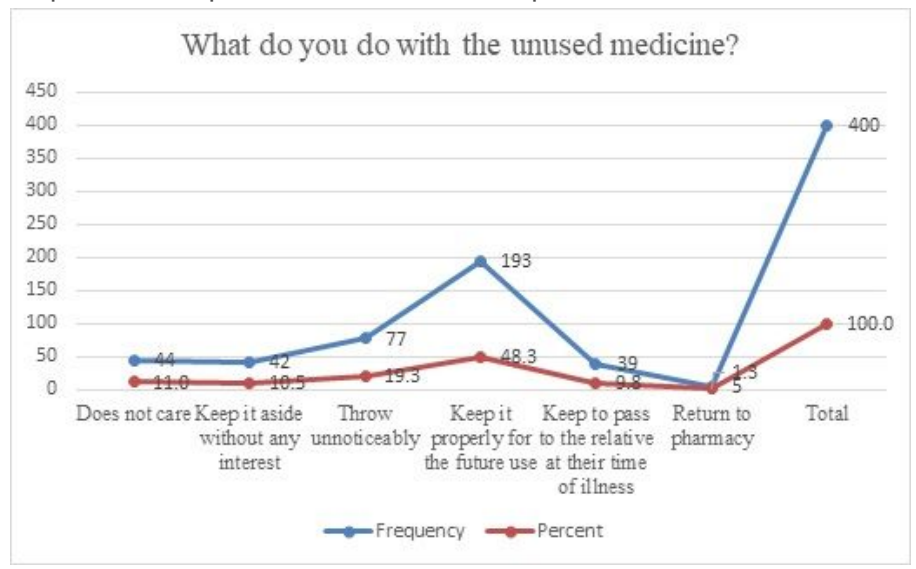

\section{Figure 2}

What do you do with the unused medicine?

\section{Supplementary Files}

This is a list of supplementary files associated with this preprint. Click to download.

- Equatornetwork.docx

- TakebackAnnex.docx 